\title{
EXISTENTIALISM IN EDUCATION
}

\author{
Matrika Prasad Koirala \\ Department of Education
}

\begin{abstract}
This paper is an attempt to survey the historical development of existentialist philosophy, meaning of existence, its philosophical premises and perspectives. Further, this also deals with implications of existentialism in selection of aim of education, organization of curriculum, role of teachers and students and school organization.
\end{abstract}

\section{Keywords}

Existence, nihilistic, being-in-itself, being-for-itself, individuality

\section{Introduction}

Many think that existentialism is not philosophy as idealism or pragmatism. They consider existentialism as an approach to philosophy rather than a system of philosophical thought. Nothing has been said in the primary literature of existentialism about education. It is a broad generalization to say that no important figure in existential philosophy has had anything significant to say about education, yet is true. There is no indication that education policy is considered by existentialist as important. Existential thought has much in it that is directly relevant to religion and to what in the broad sense; at least we should call psychology, but of education there is little said directly. Why it should be so is a provocative question for me. In our previous inquires, we have been able to find specific connection of one kind or another between philosophic ideas and educational ideas.

\section{Development of existentialism}

Hindu philosophy is an extension, interpretation, criticism and corroboration of the Vedas and in it the Upanishads or an outright revolt against them. Similarly it may be remarked of western philosophy as either a clarification of Socrates philosophy or his rejection. One would be still right in saying that the whole of western philosophy is an appendix on Socrates. So it is even true with existentialism that Socrates has been considered to be the first existentialist. "Know thyself" was Socrates admonition (Wingo, 1975). Certain features of existentialism are found in Hindu philosophy, as there is insistence on the knowledge of the self, Janna, and in 


\section{M.P. Koirala}

Buddhist philosophy, which seeks enlightenment, "bodhi". There are a number of correlates in Hindu philosophy for existential concepts e .g. anguish, dukha, dread and horror; bhagya etc Chaube \&Chaube(1991). Plato, Spinoza Leibnitz, Descartes and also majority of western thinkers believe in the immutability of ideas and the rest of the thinkers have been suggesting correctives to it. The last in the series was Hegel who carried farthest this effort to understand the world rationally.

Reason and nature were given more importance during the eighteenth century. As a result, there were industrial and technological developments and science was given greater importance. Objectivity was very much encouraged. This situation curtailed the freedom of individuals and they became puppets in the developing industrial society. Machines were handmade, but they became slaves to them. From the scientific viewpoint, like other aspects of nature; man was also regarded as an object of exploitation. Against this developing situation, existentialism emerged as a protest against the society, the state and the world and asserted the supremacy of the individuality of man(Chaube \& Chaube ,1995).

Existentialism found great recognition and popularity during the twentieth century (Wikipedia, 2011). Five men are generally conceded to be the leading figures in existentialism. They are Soren Kierkegaard (1815-1855), Friedrich Nietzsche (1844-1900), Martin Heidegger ( 1899 -1976), Karl Theodor Jaspers ( 1883-1969) and Jean Paul Sartre (1905-1980). Edmund Husserl(1859-1938), and Gabriel Marcel(1889-1973) were very much influenced by existentialism.

\section{Meaning of existence}

Etymological meaning of existence from two German words- 'ex- sis tent' meaning that which stand out, that which 'emerges' suggests that existentialism is a philosophy that emerges out of problems of life. To existentialism, the existence of the individual doesn't mean only by 'his being alive'. It stands for the full, responsible and progressive life of the individual in the ever-developing industrial society. Humans should get an opportunity for subjective consciousness. Truth is realized only in inner life. As modern mechanical / industrial life has taken away individual freedom from man, existentialism lays emphasis on freedom and individual responsibility. It has an eye-view on human weakness and insecurity as man is leading a lonely life being surrounded by anxieties, frustrations, fear, feeling of guilt etc. Their individuality is being crushed.

\section{Views on existentialism}

Soren Aabye Kierkegaard (1813-1855)

Kierkegaard is regarded as the father of existentialism (Feibleman, 1973). Kierkegaard's original and extremely important contributions to existentialist philosophy are under three categories. First, there is Kierkegaard's interpretation of the essentially subjective nature of human existence; his insistence on the complete freedom of the individual to chose and to become what he wills himself to become; and his consequent denial of determination and the priority of essence over existence. Secondly, there is his protest against institutionalized Christianity that seeks to understand and make clear what is paradoxical and absurd and therefore outside the possibility of human reasons. Third, there is Kierkegaard's analysis of the human conditions as being one of despair and anxiety, at the root of which lies the necessity for choice in a world that is completely undermined.

\section{Friedrich Nietzsche (1844-1900)}

Nietzsche was without any doubt one of the aesthetic geniuses of the nineteenth century, but his genius often was an erratic as it was brilliant. Nietzsche, like Kierkegaard, had basic religious theme, but he treated it very differently. Kierkegaard believed the Church killed religion, but he believed that God exists and can be known, although not in the 
formalistic sense that the Church prescribed. Nietzsche went beyond and insisted that religion is dead because god is dead.

The root of Nietzsche's ethical relativism lies in his prediction that a new episode in history is to begin with an era that will be nihilistic so far as the old, conventional values are concerned. Nietzsche was influenced by the Darwinian conception of nature as evolutionary. In this view, life is on a continuous process of evolutionary development (Wingo, 1975).

\section{Martin Heidegger (1889-1976)}

Heidegger does not accept himself as an existentialist but from the philosophical he is an existentialist (Chaube \& Chaube, 1995). He made a deep study of history but Greek philosophy has been the main source of his philosophical ideas. According to him, the individual may experience his 'self' by living in the World itself. The following two kinds of things are found in the world: a. Those things that was present in the world before man was born.b. Those things that man uses as a means. According to Heidegger, man's knowledge is a result of interaction between the mind and object of the world. Knowledge comes through the insight of the individual. This knowledge expands further, through "self". Freedom is necessary for obtaining this knowledge. Free dom is essence of truth.

Jean Paul Sartre (1905-1980)

One of the fundamental concerns in Sartre's philosophy is the ontological question of being, which is the great concern of Heidegger as well. Perhaps, the most important aspect of Sartre's treatment is his distinction between two forms of being: being-in-itself and beingfor-itself. By being-in-itself, Sartre means the self-contained being of things: what we in common speech call object that is, trees, stones, chairs, tables, and so forth are examples of being-in-itself. They are what they are in themselves. On the other hand, beingfor-itself is a realm of human consciousness and essential fact of consciousness is that it is always outside of and ahead of itself.

\section{Philosophical premises of existentialism}

Existence precedes Essence: It means that, first of all man exits, turns up, and appears on the scene, an only afterwards defines him. As a man has no essence, he can only have history; thus there cannot be an abstract man, but only individual man, existing in time and space of history. If at all, man acquires his essence, he does so at the moment of his death because then he has no other choice left to him (Thakur, 1982).

The fact of freedom: One of the important ideas in the existentialist tradition is that man is free to choose and his choices are undetermined by external conditions. In this sense, existential philosophers emphasize the principle of indeterminism as to oppose various deterministic theories of nature and human behavior. However, freedom of man plays an important part in the thought of most existentialist philosophy (Wingo, 1975).

No acceptance of readymade concepts: Existentialism believes that man cannot accept the readymade concepts of existence forced upon him. He is a free agent capable of shaping his own life and choosing his own destiny.

Man is not alone in the world: Man is connected to other man; he communicates to others; therefore, he cannot live in a state of anarchy. Life is seen as a gift, which, in part is mystery. Man is free choosing commitments' in life, in his choice, he becomes his self. He is the product of his choice.

Truth is introvert and subjective: Existentialist advocated that the truth should be really experienced in one's life. The existence of individuality will be powerful only when the truth gives self-satisfaction. In fact, truth should give self-satisfaction.

Death and nothingness: Existentialist believes that existence of a person means his period from birth to death. There was nothing before birth and would be nothing beyond death. In between we have been thrown in to a social 


\section{M.P. Koirala}

life and the characteristics of this social life are the contingent circumstances of our life. This contingency is often characterized by experience of dread, horror, anguish, solitude, bewilderment uncertainty and finally limited by death.

Self knowledge: The existentialist considers 'self -know- thyself' as the basic premise of this philosophy (Aggarwal, 1985).

Having reviewed the major elements of the existentialist school, now I would like to turn to consider the implications of existentialism to education:

\section{Educational implications}

\section{Aim of education}

- The aim of education is to assist a feeling, suffering, and rejoicing, free person fashion an essence for himself (Dhakal \& Koirala, 2066, p. 75).

- The duty of the practitioner of education is to assist the students to assume responsible selfhood, to grow up and face the world responsibly.

- Education is for full development of the individuality of the individual.

- Education is to contribute in the realization of self.

- Education must make up pupils aware of the infinite possibilities of his freedom and the responsibilities he must bear in life.

- Education should create consciousness for self.

- Every individual is unique. Education must develop to individual differences.

\section{Curriculum in existentialism}

The existentialists are skeptical of the traditional approach to curriculum in which fixed quantities and selected qualities of knowledge and skill, determined by adult person or specialist bodies are passed on by teachers to learners. Even this approach is not popular with existentialists. As they take a stand that nothing is fixed, final, absolute or finite, the "boxes of knowledge" approach is likely to challenge students to define themselves too soon (Thakur, 1882).

The existentialists reject any subject matter that is unrelated to human aspiration, needs and conditions. They offer suggestions on how to use the existing subjects properly. For example, social studies is not for adjustment as treated traditionally but is for the "dreaded freedom"; and history should not merely concern itself natural events but with activities of men who were free to choose the line of their action. Scientific subjects and mathematics should be included in the curriculum but they should not be given more stress, as they deal with objective knowledge. Self knowledge precedes universal knowledge.

\section{Teaching method}

The existentialist philosophy advocates the Socrates method as a model. The way in which Socrates conducted his teaching, at least as it is portrayed by Plato, and the kind of relationship he established with various ideas we have discovered in existential philosophy. His method of teaching was one of asking questions, refining answer, asking more questions, and pushing the issue until some acceptable conclusion was reached. Existentialists reject the group method, because in-group dynamic, the superiority of the group decision over individual decision is prominent. There is a danger of losing unique individualism and free choice.

Role of teachers and students we find that in this philosophy, the teacher is not treated as a technician. Harper develops role of the teacher when he says that "the good educator know that he is educating individuals, not just man, and will use any method 
that will educate the whole man. Not even the whole man, but is his humanity as well (Haper, 1955).

Existentialists do not wish the teacher to be social minded umpire or provider of free activity (as the pragmatists want) or a model personality (as the idealist say) to be limited by the students. He must himself be a free personality, engaged in such a relation. Teachers should avoid applying labels to children (such as' lazy' 'slow learner' etc) for individuals may indeed come to think of themselves this way. The teacher is also changing and growing as he guides the pupil in his discovery of self.

The existentialists want to give full freedom to the child. But the child should know his 'self' and recognize his being and convert imperfection into perfection. Under the guidance of the teacher, the student should try to realize his self. The student accepts the discipline prescribed by the teacher and does not become irresponsible. The child has to make choice and decision.

\section{School in existentialism}

The school should provide an atmosphere where the individual develops in a healthy way. Democratic ideals should pervade the school. Democracy must be the soil in which the individual grows. Mechanization and impersonality should be counteracted in school. Student's timetables and work programs are computerized. And thus the relationship between the individual students and the school programmed becomes an impersonal one. Besides, the use of programmed instruction, teaching machines and other equipments tends to decreases the personal contact between teachers and pupils. This impersonality is a hazard to the individual development and growth of the child's personality. Mass teaching and mass testing is not advocated in schools. The school should provide an environment where the individual find security, encouragement and acceptance by teachers.

\section{Conclusion}

Existentialism opposes exploitation of man and is against the repressive of his individuality but emphasizes the existence of individuality, thinking as introvert and subjective phenomenon. Education is to contribute in the realization of self. Subjective knowledge is considered more important. It is beneficial to selection of educational policy, formulation aim of education, organizing curriculum, and selection of effective pedagogy. It also applies in organizing school programs and classroom practices.

\section{References}

Aggarwal, J. C. (1985). Theory and principles of education. New Delhi: Vikas Publishing Houses Pvt.

Chaube, S. P. \& Chaube, A. (1995). Foundations of education. New Delhi: National Publishing House.

Chaube, S. P. \& Chaube, A. (1991). Philosophical and sociological foundation of education. Agra: Vinod Pustak Bhandar.

Chaugule, S. S. (2009). Existentialism in education. Articlesbase, Free online Articles

Dictionary (2009). Retrieved on 17 June 2011 from http:/www.articlebase.com/education-articles/existentialism in education 12339/.html

Dhakal, M. P. \& Koirala, M. P. (2066). Foundations of education. Kathmandu: Ratna Pustak Bhandar.

Feibleman, J. K. ([1988). Understanding philosophy, Bombay: Jaico Publishing.

Harper, R. (1955). Significance of Existence and Recognition for Education, Modern Philosophies of education, Fifty-fourth yearbook of the National Society for the Study of Education, part 1, Nelson B. Henry(ed.), Chicago. 


\section{M.P. Koirala}

Thakur, A. S, (1982). The philosophical foundations of education. New Delhi: National Publishing House.
Wingo, G. M. (1975). Philosophies of education: An introduction. New Delhi: Sterling Publishers Private Limited.

\section{The Author}

Matrika Prasad Koirala is a Lecturer in Education in Thakur Ram Multiple Campus, Birgunj. He has been teaching various courses such as Foundations of Education, Social Justice and Educational Psychology for the last thirteen years. He has co-authored a book on education. His subject of interest includes educational philosophy. 